Statesmen and Politicians of the Stuart Age 


\section{Statesmen and Politicians of the Stuart Age}

EDITED BY

TIMOTHY EUSTACE

Macmillan Education 
ISBN 978-0-333-31827-0 ISBN 978-1-349-17874-2 (eBook)

DOI 10.1007/978-1-349-17874-2

Introduction, editorial matter and Chapters 6, 7, 8 and 9

(C) Timothy Eustace 1985; Chapters 1, 4 and 5 (C) Jonathan Watts, 1985; Chapter 2 (C) Donald Wilkinson 1985; Chapter 3 (C) Jeremy

Ward 1985; Chapter 10 (C) Rod Martin 1985

Softcover reprint of the hardcover 1st edition 1985

All rights reserved. For information, write:

St. Martin's Press, Inc., 175 Fifth Avenue, New York, NY 10010

Published in the United Kingdom by Macmillan Publishers Ltd.

First published in the United States of America in 1985

ISBN 978-0-312-75729-8

Library of Congress Cataloging in Publication Data

Main entry under title:

Statesmen and politicians of the Stuart age.

Bibliography: p.

Includes index.

1. Statesmen-Great Britain-Biography-Addresses, essays, lectures. 2. Great Britain-History-Stuarts, 1603-1714-Biography-Addresses, essays, lectures.

I. Eustace, Timothy.

DA307.S72 $1985 \quad 941.06^{\prime} 092^{\prime} 2 \quad 84-18223$

ISBN 978-0-312-75729-8 


\section{Contents}

List of Plates vii

Preface ix

Introduction 1

TIMOTHY EUSTACE

1 Lionel Granfield, Earl of Middlesex 17

JONATHAN WATTS

2 George Villiers, Duke of Buckingham 37 DONALD WILKINSON

3 William Laud, Archbishop of Canterbury 61 JEREMY WARD

4 Thomas Wentworth, Earl of Strafford 83 JONATHAN WATTS

5 John Pym 115 JONATHAN WATTS

6 Sir Henry Vane the Younger 141 TIMOTHY EUSTACE

7 Edward Hyde, Earl of Clarendon $\quad 157$ TIMOTHY EUSTAGE

8 Anthony Ashley Cooper, Earl of Shaftesbury 179 TIMOTHY EUSTACE

9 Thomas Osborne, Earl of Danby 201 TIMOTHY EUSTACE AND ROD MARTIN 
vi CONTENTS

10 Robert Spencer, Earl of Sunderland 223 ROD MARTIN

Bibliography 243

Notes and References 249

Notes on Contributors 255

Index

256 


\section{List of Plates}

1 Lionel Cranfield, Earl of Middlesex, by Daniel Mytens (courtesy of the Lord Sackville, Knole; photograph: Courtauld Institute of Art)

2 George Villiers, Duke of Buckingham, sketch by Rubens (courtesy of the Kimbell Art Museum, Fort Worth, Texas; photograph (C) John Denman)

3 William Laud, Archbishop of Canterbury, copy of Van Dyck (courtesy of St John's College, Oxford)

4 Thomas Wentworth, Earl of Strafford, with Sir Philip Mainwaring, by Van Dyck (courtesy of the Trustees of the Rt Hon. Olive, Countess Fitzwilliam's Chattels Settlement and the Lady Juliet de Chair)

5 John Pym, by Samuel Cooper (private collection; photograph: Courtauld Institute of Art)

6 Sir Henry Vane the Younger (courtesy of the Lord Barnard, Raby Castle; photograph: Courtauld Institute of Art)

7 Edward Hyde, Earl of Clarendon, after Hanneman (courtesy of the National Portrait Gallery)

8 Anthony Ashley Cooper, Earl of Shaftesbury, after J. Greenhill (courtesy of the National Portrait Gallery)

9 Thomas Osborne, Earl of Danby, studio of Lely (courtesy of the National Portrait Gallery)

10 Robert Spencer, Earl of Sunderland, the English School (courtesy of Blenheim Palace) 


\section{Preface}

THIS collection of essays results from the dissatisfaction expressed by many involved in teaching seventeenth-century British history at the dearth of accessible and up-to-date biographies of those statesmen and politicians who dominate any study of the period. There are few studies of a length suited to the pressures on most students. There are indeed excellent studies of Buckingham, Shaftesbury and Sunderland, and a new biography of Clarendon, but the standard works on men such as Cranfield, Laud and Pym need some reinterpretation as a result of the mass of revisionist work on the first half of the century. This volume attempts at least a partial solution to this problem by providing studies of ten significant statesmen and politicians, each essay aiming to provide relevant and revealing biographical information whilst also examining and explaining the situation in which each statesman found himself: the problems of the government at that time; the personal difficulties inherent in the circumstances of Court life; the specific administrative, financial or religious problems each was required to solve to achieve any kind of success. Each essay must of necessity, owing to its brevity, be essentially a synthesis of known material and interpretation; yet each attempts within such limited space a clear statement on the motivation, successes or failings, and significance of its subject. By such emphasis on analysis of the issues which dominated the century the intention is to create a series of studies which avoid the limitations of mere potted biography.

There are many difficulties that result from this approach. Economics have dictated tight curbs on the length of each essay. All readers, and it is hoped that not only students will find this volume of interest, will need some prior knowledge of the seventeenth century, since there is no space to explain every development, especially those only indirectly connected with the individual subject. Reference to the notes and bibliographies (themselves only a selection of the more accessible sources) will be needed by the reader who wishes to 
discover more information about the evidence used to adduce the interpretations. Since the bibliographies have been assembled for the student or teacher rather than the professional scholar, I must beg the indulgence of those historians who may recognise their ideas and research behind some of the material, yet who receive no direct recognition.

My own thanks must go first to my fellow contributors for so uncomplainingly accepting the restrictions and demands imposed upon them. I should also like to thank Mr David Maland for his assistance with my initial steps towards arranging publication. Particular appreciation and gratitude is due to Sarah Mahaffy, of Macmillan Press, who has been a most tolerant, sympathetic and helpful adviser and guide, and to Vanessa Peerless for her assistance during the various stages of publication. Finally warm gratitude goes to my wife for her forbearance whilst this volume has been in preparation, and especially for her invaluable assistance in the checking of the typescripts and proofs, a thankless task to which she has devoted many uncomplaining hours.

Timothy Eustace 